DOI: https://doi.org/10.34305/nnc.v1i1.118

\title{
HUBUNGAN ANTARA KECANDUAN GAME ONLINE DENGAN TINGKAT DEPRESI PADA REMAJA DI DESA GARAWANGI KUNINGAN
}

\author{
${ }^{1}$ Lia mulyati, ${ }^{2}$ Andi Sutandi \\ ${ }^{1}$ Sekolah Tinggi Ilmu Kesehatan Kuningan Garawangi \\ ${ }^{2}$ RSD 45 Kuningan \\ liamulyati@stikku.ac.id
}

\begin{abstract}
Abstrak
Fenomena game online menjadi trend masa kini. Dan Indonesia, pengguna game onlinenya $50 \%$ sudah tergolong pecandu. Kecanduan game online dapat membuat pemain beresiko mengalami gangguan mental seperti depresi. Penelitian ini bertujuan untuk mengetahui hubungan antara kecanduan game online dengan tingkat depresi pada remaja di tempat game online Desa Garawangi.

Penelitian ini termasuk jenis penelitian analitik dengan rancangan cross sectional dengan responden penelitian berjumlah 71 orang yang sudah memenuhi kriteria yang sudah ditentukan yang diambil secara accidental sampling. Data penelitian diolah dan dianalisis menggunakan uji Rank Spearman.

Hasil penelitian menunjukkan bahwa dari 19 orang $(26,7 \%)$ yang tidak mengalami kecanduan game online, 8 orang $(42,1 \%)$ tidak mengalami depresi. Sedangkan responden yang mengalami kecanduan game online dari 52 orang $(73,2 \%)$, sebagian besar mengalami depresi berat yaitu 27 orang (51.9\%). Hasil analisis bivariate di dapatkan nilai $p \quad 0,028$ dengan $r 0.261$.

Kesimpulan dari penelitian ini adalah terdapat hubungan antara kecanduan game online dengan tingkat depresi pada remaja. Penanganan yang tepat yaitu dengan melibatkan orang tua, guru, perawat komunitas, serta penjaga warnet game online untuk memperhatikan anak bermain serta membatasi melakukan permainan yang berlebihan serta dapat mengalihkan dengan kegiatan yang lebih penting dan positif lainnya.
\end{abstract}

Kata Kunci: kecanduan, game online, depresi

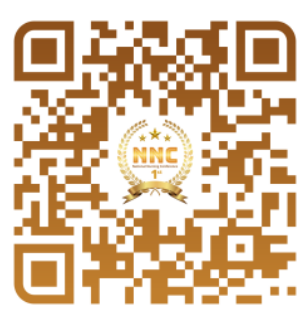

